Research Journal of Applied Sciences, Engineering and Technology 5(6): 1923-1927, 2013

DOI:10.19026/rjaset.5.4730

ISSN: 2040-7459; e-ISSN: 2040-7467

(C) 2013 Maxwell Scientific Publication Corp.

Submitted: June 08, $2012 \quad$ Accepted: August 08, $2012 \quad$ Published: February 21, 2013

Research Article

\title{
Comparing AlGaAs-GaAs Heterojunction Materials with CdS-InP Anisotype for Solar Cells Efficiency in Concentrator Systems
}

\author{
${ }^{1}$ Tina Sojoudi, ${ }^{2}$ Nardin Avishan, ${ }^{2}$ Sanam Khalili, ${ }^{1}$ Mohammad Karimi and ${ }^{3}$ Ronak Khosravi \\ ${ }^{1}$ Young Researchers Club, Parsabad Moghan Branch, Islamic Azad University, Parsabad Moghan, Iran \\ ${ }^{2}$ Young Researchers Club, Tabriz Branch, Islamic Azad University, Tabriz, Iran \\ ${ }^{3}$ Department of Electrical Engineering, Urmia Branch, Islamic Azad University, Urmia, Iran
}

\begin{abstract}
In this study, a research was conducted for comparisons between Hetero Junction (HJ) solar cells and anis type materials. The material $\mathrm{Al}_{0.25} \mathrm{Ga}_{0.75} \mathrm{As} / \mathrm{GaAs}$ is discussed as an example of such a structure and on the other hand the $\mathrm{Cd}_{0.25} \mathrm{~S}_{0.75}$-InP anis type as an example of the solar cells is considered as an example of an anis type in which the properties of low lattice mismatch appear as an advantageous for junction transport. Finally all common junctions are experimented and results show the best efficiency for each with real amounts.
\end{abstract}

Keywords: Anis type, efficiency, hetero face, hetero junctions, solar cells

\section{INTRODUCTION}

Due to the fossil fuel resources decline and the environmental pollution and issues related to them, many scientists and countries have been looking for green energy resources based on each region's potentials. So far many kind of renewable energy sources such as solar, wind, geothermal are utilized for energy demand satisfaction. Photovoltaic (PV) energy generating systems (or PV systems) convert the sun's energy directly into electricity using state-of-the-art semiconductor materials (Farhadi et al., 2012).

Solar cells convert solar energy into electrical energy. This phenomenon occurs in materials which have the property to capture photon and emit electrons. The main material used in the photovoltaic industry is silicon. But many researchers have worked to find materials to replace or supplement on silicon to improve conversion efficiency (Rostami et al., 2011; Sojoudi et al., 2011)

The GaAs hetero face structures and the GaAs $\mathrm{n}^{+} / \mathrm{p} / \mathrm{p}^{+}$homojunction are all remarkable agreement with solar cell theory. In particular, $\mathrm{J}_{0}$ can be calculated with reasonable from measured materials properties. The $\mathrm{CdS} / \mathrm{InP}$ cell also gives a close to theoretical efficiency, but these cells frequently show tunneling transport rather than recombination/generation transport, for reasons that are not completely understood.

AlGaAs/GaAs hetero face solar cell: The band gap of GaAs $(1.43 \mathrm{eV})$ is near-optimum for solar conversion, Indicating a theoretical efficiency of $26-29 \%$ at AM1.
Because the high mobility of GaAs allows the fabrication of very-high-frequency devices and also its band gap usefully complements that of $\mathrm{Si}$, for the case of forming lattice-matched ternary compounds, GaAs rivals $\mathrm{Si}$ as the most investigated semiconductor material. GaAs has a direct band gap and large optical absorption coefficient, absorbing $97 \%$ of the AM1 photons within about $2 \mu \mathrm{m}$. The near perfect lattice match and absence of interface state recombination of the $\mathrm{AlGaAs} / \mathrm{GaAs}$ isotope junction has been used to advantage to remove the front surface recombination loss from the hetero face structure cell and to yield the highest efficiencies of any solar cell type in 1983. Because of the high cost of the material and fabrication, the present goals of the GaAs-based solar cell technology have strongly directed toward concentrator systems and space use (Cheung, 1975).

Although relatively abundant in the earth's crust (18 ppm as compared to $64 \mathrm{ppm}$ for $\mathrm{Cu}$ ), the supply of $\mathrm{Ga}$ is not large in terms of present-day refining practice. In 1980 the cost for highly purified $\mathrm{Ga}$ was some \$ $3000 \mathrm{~kg}^{-1}$ in small lots. However, the presence of Ga in fly ash from the burning of coal promises a large future source should the need warrant setting up recovery methods. Although arsenic is also quite abundant and easily won, its chemistry and the inefficiency of refining the small lots used at present makes semiconductor grade as expensive $\left(\$ 500 \mathrm{~kg}^{-1}\right)$ as well. GaAs absorbs strongly in the visible and has a zincblende cubic structure. Although minority carrier lifetimes in GaAs are quite short $\left(\sim 10^{9} \mathrm{sec}\right)$ because of the direct band-gap nature of material, the large

\footnotetext{
Corresponding Author: Tina Sojoudi, Young Researchers Club, Parsabad Moghan Branch, Islamic Azad University, Parsabad Moghan, Iran

This work is licensed under a Creative Commons Attribution 4.0 International License (URL: http://creativecommons.org/licenses/by/4.0/)
} 


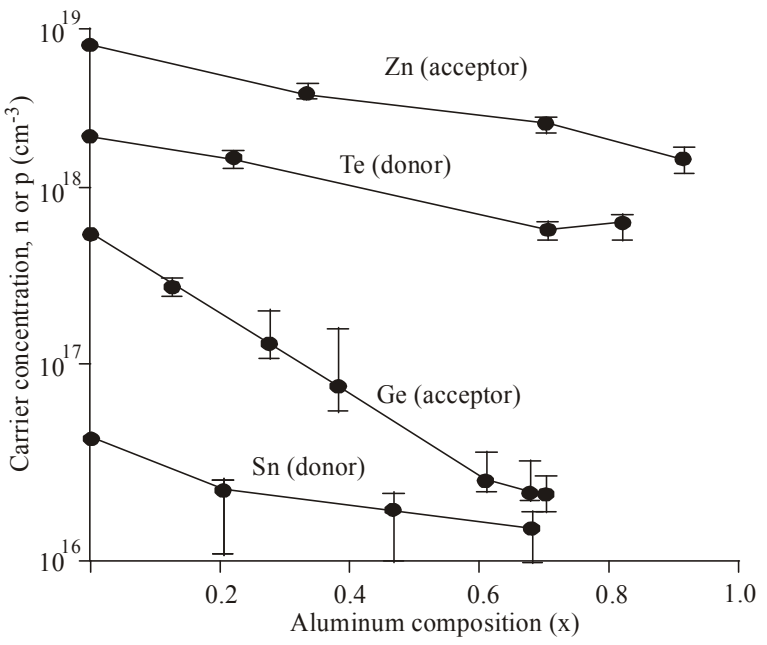

Fig. 1: Carrier concentration in $\mathrm{Al}_{0.25} \mathrm{Ga}_{0.75}$ As layer versus $\mathrm{Al}$ composition for four dopants

mobility gives diffusion lengths quite sufficient for high quantum efficiencies (6-8 $\mu \mathrm{m}$ in LPE GaAs: GE). Cells made from $\mathrm{AlGaAs}$ must be encapsulated since $\mathrm{Al}$ $\mathrm{GaAs}$ is hygroscopic at high $\mathrm{Al}$ concentrations. Crystal growth of the material is usually by the Bridgman technique, although the Czochralski method can also be used. Synthesis from the elements must be done carefully to avoid explosion. Because of the large difference in the vapor pressure $\left(\mathrm{P}_{\mathrm{Ga}}=3 \times 10^{4}\right.$ atm at $1240^{\circ} \mathrm{C}$ and $\mathrm{P}_{\mathrm{As}}=1$ at $\mathrm{m}$ at $615^{\circ} \mathrm{C}$ over the elements) and arsenic overpressure must be used during growth to preserve stoichiometry. Crystal growth can also be accomplished by chemical vapor deposition and by growth from solution; these are the most common means of fabrication of solar cells from these materials. Do pants include $\mathrm{S}, \mathrm{Se}, \mathrm{Te}, \mathrm{Sn}, \mathrm{Si}, \mathrm{C}$ and $\mathrm{Ge}$ as shallow donors and $\mathrm{Zn}, \mathrm{Be}, \mathrm{Mg}, \mathrm{Cd}, \mathrm{Si}, \mathrm{Ge}$ and $\mathrm{C}$ as shallow acceptors. The column IV elements-C, Si, Ge and Sn- are amphitricha in GaAs and their electrical activity in the crystal depends on growth conditions. For example Ge is substitution on an as site, acting as an acceptor for growth near $900^{\circ} \mathrm{C}$, whereas for growth near the melting point $\mathrm{Ge}$ substitutes on a $\mathrm{Ga}$ site as a donor. $\mathrm{Zn}$ is volatile and fast diffusing and thus easy to introduce in diffused junctions, but Ge and be appearing to give the highest lifetimes among the common acceptor do pants. Te appears to be the do pant of choice as a donar impurity. The low atomic diffusivity of both $\mathrm{Ge}$ and $\mathrm{Te}$ make it necessary to introduce them during the growth of layers rather than by post growth diffusion. Do pants generally become less electrically active with increasing $\mathrm{Al}$ content in $\mathrm{Al} \mathrm{GaAs}$, as shown in Fig. 1.

Recombination centers active in GaAs are similar to those in $\mathrm{Si}(\mathrm{Cr}, \mathrm{Fe}, \mathrm{Ni}, \mathrm{Cu}$ and $\mathrm{Ag}$ ) but also include oxygen. $\mathrm{Al}_{\mathrm{x}} \mathrm{Ga}_{1-\mathrm{x}} \mathrm{As}$ fulfills the need for an adjustable band-gap counterpart for GaAs with an exceptionally good lattice match (only $0.16 \%$ mismatch between Alas and $\mathrm{GaAs}$ ). And growth methods involving $\mathrm{AlGaAs}$ have the ability to form clean interfaces. Figure 2 shows the energy band gap versus lattice constant for $\mathrm{Al}, \mathrm{Ga}$, In, P, As, Sb compounds Shen (1995).

LPE and CVD layered structures: The fabrication of layered structures by liquid phase epitaxial LPE depends on the solubility of As in liquid Ga and $\mathrm{AlGa}$ alloys and the subsequent precipitation of $\mathrm{Al}_{\mathrm{x}} \mathrm{Ga}_{1-\mathrm{x}} \mathrm{As}$ layers onto crystalline substrates, which determine the crystallographic orientation of layers. The growth apparatus shown in Fig. 3 is fabricated of high-purity carbon and quartz and growth occurs in an ambient of high-purity $\mathrm{H}_{\mathrm{z}}$. The top portion, containing the Ga melt, slides over the bottom, which contains both the substrate and a GaAs source. After the melt has been saturated at $\mathrm{T} \sim 900^{\circ} \mathrm{C}$ over the GaAs source, the slider carries the Gamelt over the substrate and the

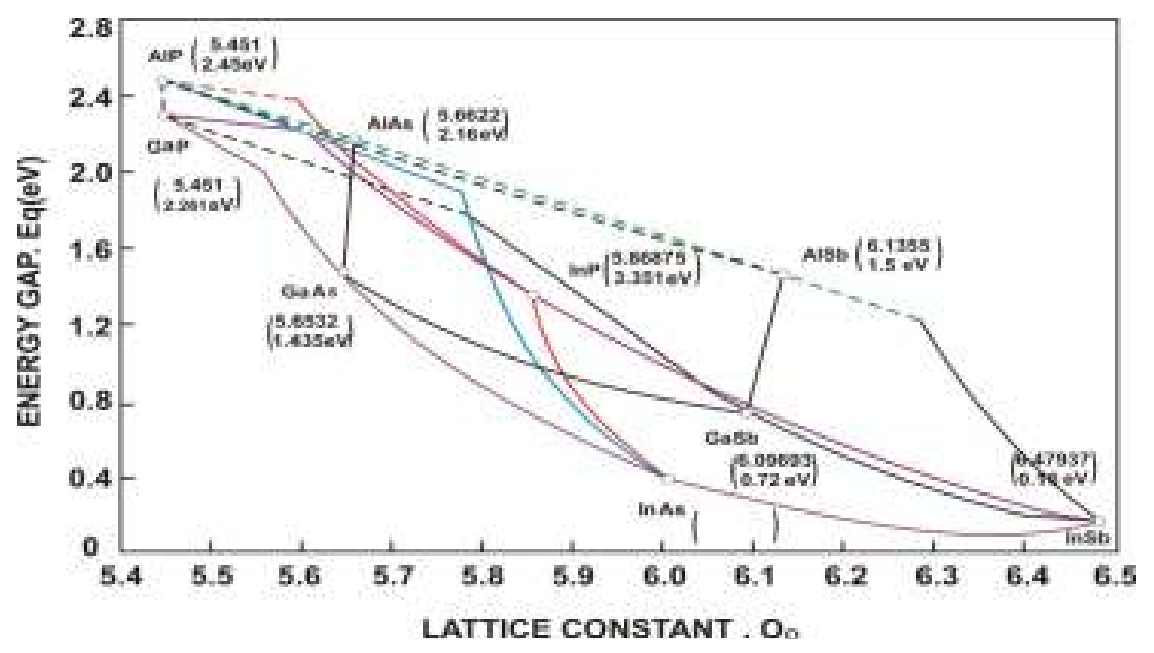

Fig. 2: Energy gap versus lattice constant of binary and compound systems 

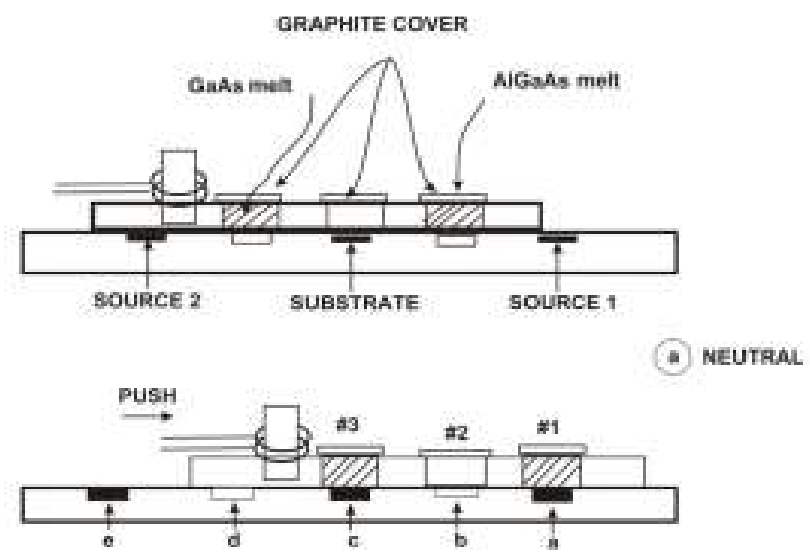

GROWTH of GaAs

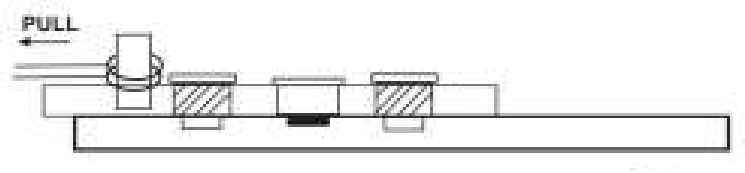

C GROWTH of AUGaAs

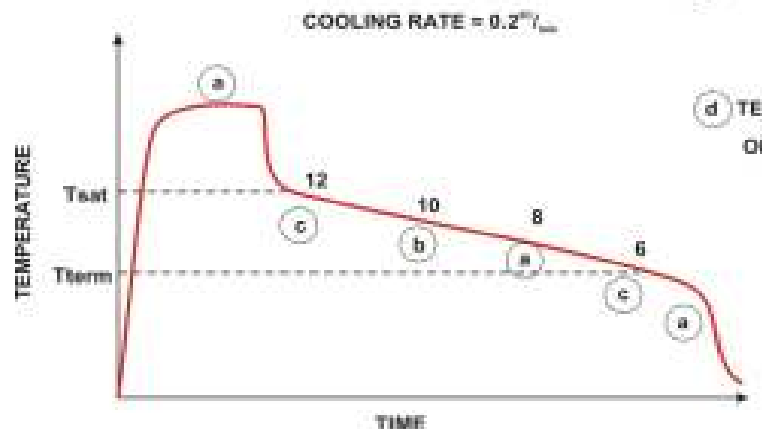

TENPERATURE CYCLE

OF A TYPICAL GROWTH

Fig. 3: Cross section of LPE growth system and temperature-time profile during growth of Al GaAs layers

temperature is lowered at a rate of $0.1-0.5^{\circ} \mathrm{C} / \mathrm{min}$. The solubility-versus-temperature data are shown in Fig. 4.

Growth rates of $0.1-0.5 \mu \mathrm{m} / \mathrm{min}$ are obtained. Durning deposition the relatively large volume of $\mathrm{Ga}$ acts as a sink for segregated impurities, since the growth proceeds very near thermal equilibrium, the resulting epitaxial layers are of very high quality. To stabilize the growth, temperature gradients are sometimes established across the freezing front by cooling devices, producing layers of very uniform thickness and preventing the formation of hillocks. The oxygen partial pressure must be kept as low as possible since $\mathrm{O}$ is an active recombination center in GaAs. During the initial moments of deposition there is, in some cases, a small dissolution of the GaAs substrate, which ensures an atomically clean interface and accounts for the low recombination velocities observed at the metallurgical interface. By adding small quantity of $\mathrm{Zn}$ to the $\mathrm{Al}$, Ga melt, a shallow p-type layer can be formed in the GaAs substrate simultaneously with the formation of the AlGaAs layer. Alternatively, a separate $\mathrm{p}$-GaAs layer can be grown from a Ge-doped $\mathrm{Ga}$ melt prior to the growth of the AlGaAs layer. The diffused layer and the growth layer are two major alternatives for this sort of device. Naively, one would expect greater crystalline perfection and longer lifetime in the growth layers. Several variations on LPE growth are used to enhance the properties of the devices. Deposition can take place using under saturated, saturated, or supersaturated melts, the latter typically giving smaller minority carrier diffusion length $\mathrm{L}$ in the grown layer. "Leaching" or guttering of impurities from the underlying $\mathrm{p}$ or $\mathrm{n}$ substrate layers to enhance I, Can be accomplished by annealing the substrate in the $\mathrm{Ga}$, Al melt before growth.

Both guttering and growth of compositionally graded $\mathrm{Al}_{\mathrm{x}} \mathrm{Ga}_{1-z}$ layer in a single step. The other major growth method for films of $\mathrm{Al}_{\mathrm{x}} \mathrm{Ga}_{1-\mathrm{z}} \mathrm{As}$ is chemical vapor deposition CVD (or, more restrictively, Vapor Phase Epitaxy (VPE)) by synthesis from gaseous $\mathrm{Ga}$ and as compounds. By reaction of $\mathrm{GaCl}_{3}$ and arsine $\left(\mathrm{AsH}_{3}\right)$ on a substrate at $600-800^{\circ} \mathrm{C}$, growth rates for $\mathrm{GaAs}$ of $>10 \mu \mathrm{m} / \mathrm{h}$ can be achieved.

Deposition can also be accomplished by paralysis reaction of organ metallic $\mathrm{Ga}$ compounds (e.g., trimethylgallium) and $\mathrm{AsH}_{3}$ at an rf-heated substrate 


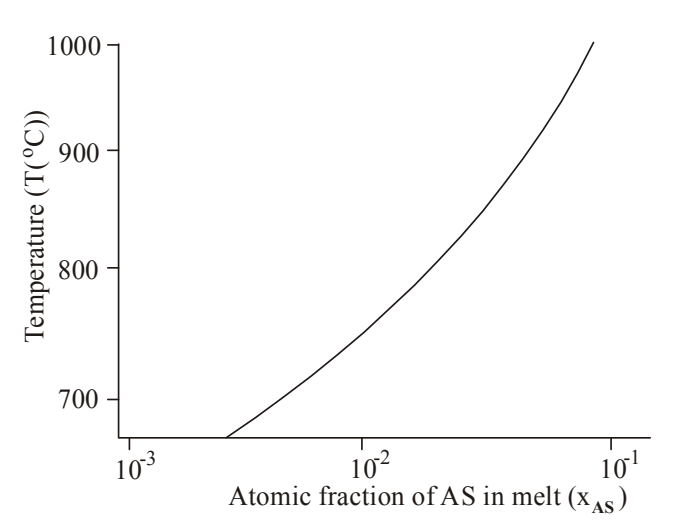

Fig. 4: Solubility of As in liquid Ga versus temperature

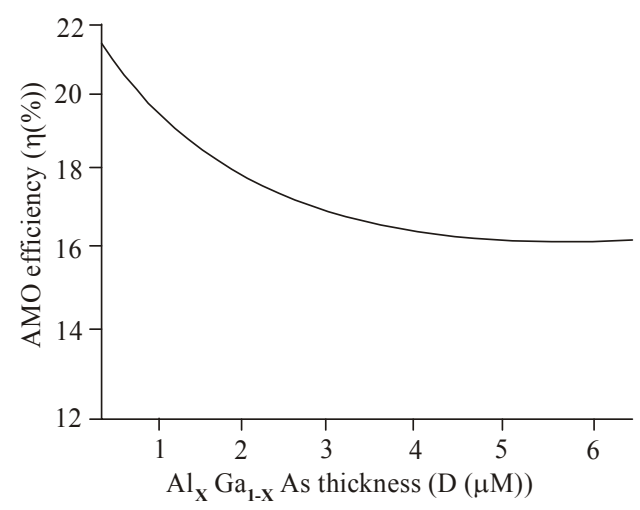

Fig. 5: The effect of AM0 efficiency as a function of the $\mathrm{Al}$ GaAs on $\eta_{\text {s }}$

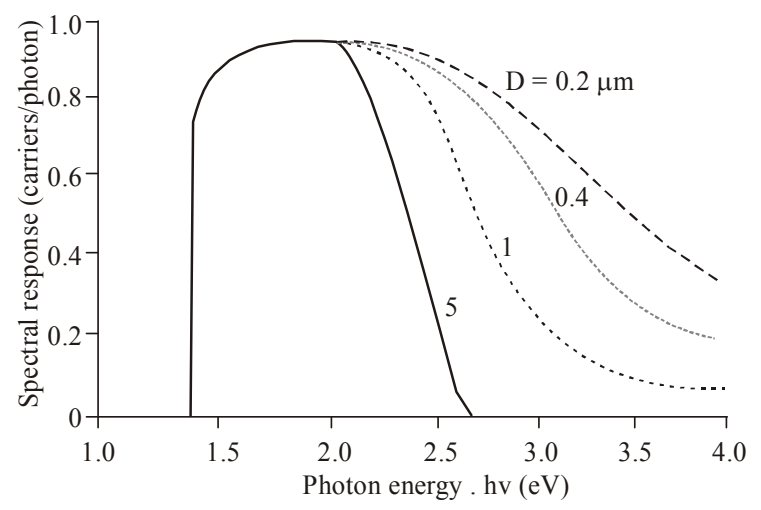

Fig. 6: Calculated effect of decreasing the window thickness $\left(x^{\prime}{ }^{-}-x_{p}^{\prime}\right)$ for AM0 conditions, thickness $D$ as the independent variable

(MO-CVD). A particular advantage of the latter technique with regard to future cale-up is that it is done in a cold wall reactor and material is deposited only on heated areas. Both processes utilize $\mathrm{H}_{2}$ as a carrier gas at atmospheric pressure.

Lifetimes are comparable in layers grown by both LPE and CVD. Both methods can be also used to deposit polycrystalline GaAs films on amorphous
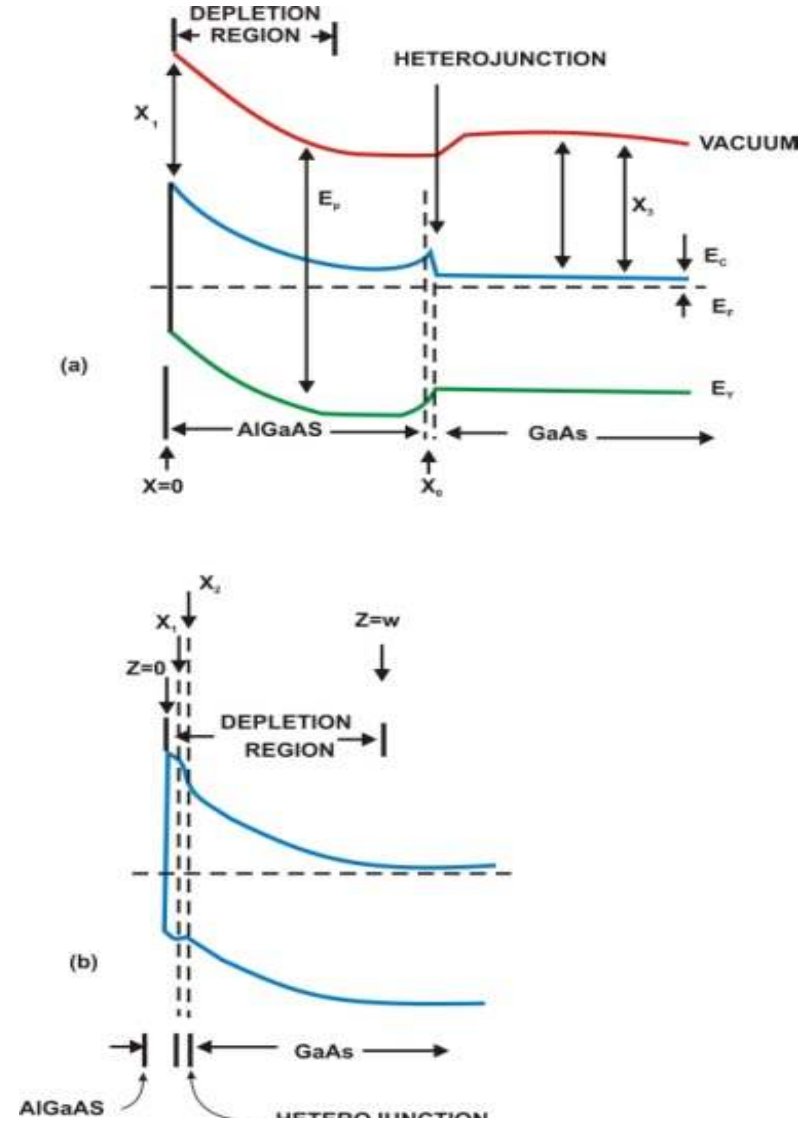

Fig. 7: Energy band diagram of $\mathrm{Au} / \mathrm{n}-\mathrm{AlGaAs} / \mathrm{n}-\mathrm{GaAs}$ schottky barrier solar cells, the thickness of AlGaAs layer is greater than the depletion layer width in part (a) and smaller than the depletion layer width in part (b)

substrates. Because of the extreme difference in vapor pressures of the elements (a ratio of $10^{11}$ at $400^{\circ} \mathrm{C}$ ) stoichiometry is impossible to maintain in standard vacuum evaporation of GaAs from the compound.

The GaAs-based solar cell-basic structure and preliminary optimization: Fraction of the total $\mathrm{J}_{\mathrm{L}}$ is generated in this window layer and so the relative loss is small. Because of good lattice matching and because the fabrication processes can produce clean interfaces, the recombination loss at the $\mathrm{AlGaAs} / \mathrm{GaAs}$ interface is small. Indicate values of $\mathrm{S}_{1}<10^{4} \mathrm{~cm} / \mathrm{sec}$.

Because the $\mathrm{p}^{4}$ layer also serves for lateral current collection in most cases, the resistivity of the thin player, where most of the useful absorption occurs. Can be optimized with regard for $L_{n}$ rather than for current collection considerations. Other EBlC measurements indicated $\mathrm{L}_{\mathrm{n}}=6.7 \mu \mathrm{m}$ for Ge doping at a doping level of $2 \times 10^{17} / \mathrm{cm}^{3}$ (Fig. 5).

The diode current-voltage characteristics of GaAsbased cells are represented remarkably well by the Shockley injection and recombination/generation 
models, for current levels corresponding to unconcentrated AM1 illumination either injection or recombination/generation.

Modes may dominated, but under high concentration most cells shod the $\mathrm{A} \sim 1$ injection behavior with corresponding low $\mathrm{J}_{0}$. Comments on the junction transport mechanisms, using the SahNoyceShockley and Choo models to calculate ultimate efficiencies for GaAs-based cells:

- Decreasing the window $\left(\mathrm{p}^{+}\right)$-layer thickness (Fig. 6)

- Optimization of the p-layer thickness. The effect of changing the p-layer thickness $\mathrm{d} \sim\left(\mathrm{x}_{\mathrm{p}+}{ }^{-} \mathrm{x}_{\mathrm{p}}{ }_{\mathrm{p}}\right)$ to maximize carrier generation and collection is shown in Fig. 7

The results suggest making the window as thin as possible consistent with its spreading resistance. These results are, of course, strongly dependent on the $\mathrm{Al} / \mathrm{Ga}$ composition chosen and the air mass number.

For GaAs-based cells the Dember voltage has only a small effect $(\sim 1 \mathrm{mV})$, since the photo generated carrier density $\left(\sim 2 \times 10^{14} \mathrm{~cm}^{3}\right.$ at $\left.\mathrm{C}=10^{3}\right)$ is small compared to the majority carrier density. Nevertheless, the high-intensity designs have light incident on the pside so that the Dember voltage adds to $\mathrm{V}_{\mathrm{oc}}$.

Three contemporary designs, all using LPE, Growth and all with $\mathrm{n}_{\mathrm{s}}>20 \%$ under high concentration, are considered here. Perhaps the major variation among them is in the thickness of the AlGaAs window: $1.2,10$ and $0.05 \mu \mathrm{m}$, respectively. Compositions of $\mathrm{x}>0.9$ are used in all. In $0.05 \mu \mathrm{m} \mathrm{AlGaAs} \mathrm{layer} \mathrm{is} \mathrm{used}$ only toreduce surface recombination rather than for current collection. These cells show a considerably larger $\mathrm{J}_{\mathrm{se}}\left(\sim 31 \mathrm{~mA} / \mathrm{cm}^{2}\right.$ when normalized to $\mathrm{C}=1100$ $\left.\mathrm{mW} / \mathrm{cm}^{2}\right)$ than do the cells designed by Ewan $(\sim 23.4$
$\mathrm{mA} / \mathrm{cm}^{2}$ at $\left.\mathrm{C}=1\right)$ or $\left(\sim 25.7 \mathrm{~mA} / \mathrm{cm}^{2}\right.$ at $\left.\mathrm{C}=1\right)$, presumably because of the difference in $\mathrm{AlGaAs}$ thickness.

This may be responsible for the somewhat lower $\mathrm{V}_{\mathrm{oc}}$ seen in these cells as compared with those in which contact is made to the $\mathrm{Al} \mathrm{GaAs} \mathrm{layer.} \mathrm{The} \mathrm{p-layer} \mathrm{of}$ these cells is more uniform in thickness. Doping is by $\mathrm{Be}, \mathrm{Mg}$, or $\mathrm{Zn}$ and $\mathrm{L}_{\mathrm{n}}=4-5 \mu \mathrm{m}$.

The lowest effective series resistance is for the cell designed by James, which utilized a $\mathrm{p}^{+}-$GaAs layer between the contact metallization and the $\mathrm{Al}$ GaAs window to obtain contact resistivity's in the $10^{-5}-10^{-4} \Omega$ $\mathrm{cm}^{2}$. All of these cells, particularly the one showed almost exact agreement with the elementary theory utilized in the computer simulation used for their design.

\section{REFERENCES}

Cheung, D., 1975. Ph.D. Thesis, Dep. Electr. Eng, Stanford Univ. Stanford California, Yoshikawa, A. and Sakai, Y. Jpn, J. Appl. Phys.

Farhadi, P., M. Karimi, B. Moradi and M. Hosseini, 2012. Feasibility study of a photovoltaic power station in the Parsabad Moghan city, Iran. Int. J. Adv. Renew. Energy Res., 1(3): 179-183.

Rostami, A., K. Abbasian and N. Gorji, 2011. Efficiency optimization in a rainbow quantum dot solar cell. Int. J. Tech. Phys. Prob. Eng., 3(7): 106-109.

Shen, L.C.C., 1995. Ph.D. Thesis, Dep. Electr. Eng, Stanford Univ. Stanford California.

Sojoudi, M., R. Madatov and T. Sojoudi, 2011. Optimization of Efficiency of solar cells by accelerated electron ray to have an optimal and constant energy. Int. J. Tech. Phys. Prob. Eng., 3(9): 68-71. 